\section{Problems of Rome University}

SIR-I am one of the associate professors of Rome University who, according to Professor Paolo Amati et al. (Nature 345, $658 ; 1990)$ publish about 0.1 papers a year in "international refereed journals". I do not know where my colleagues have collected these data, but they seem to refer to the year 1989 .

As far as I know, there is no law that compels a prospective professor to learn a foreign language so well as to publish papers in that language. In addition, most Italian scientific journals are reviewed by the Index Medicus, Current Contents, Excerpta Medical and so on. For example, the Rivista Italiana di Pediatria (Italian Journal of Pediatrics) is reviewed by Current Contents/Clinical Practice and ISI/Biomed; the European Review for Medical Pharmacological Sciences (which accepts papers also in French, German, English and Spanish) has been included in both the Index Medicus and Excerpta Medica reviews. In addition, most Italian journals require English abstracts and keywords, and publish contents in English.

My colleagues are all professors of science, whereas many Rome University professors belong to clinical/surgical dis-

\section{Duesberg replies}

SIR-Weiss and Jaffe say that I am a "flat-earther bogged down in molecular minutiae and miasmic theories of disease" for not accepting their hypothesis that AIDS is infectious. If they are right, I would indeed be "perilous" for questioning AIDS-prevention through safe sex.

As we agree that HIV (human immunodeficiency virus) fails Koch's postulates ${ }^{1.2}$, Weiss and Jaffe could prove me perilous by showing that: (1) safe sex has stopped AIDS in any country; (2) among matched groups of homosexuals, haemophiliacs or intravenous drug users, only those infected with HIV get AIDS; and (3) the mortality of American haemophiliacs has increased since 16,000 of them ( 80 per cent) became infected around 1980. Where is that proof?

And where is Weiss and Jaffe's "strong evidence against lifestyle explanations", if 97 per cent of all people with AIDS in the United States are from health-risk groups: 30 per cent intravenous drug users, 60 per cent homosexuals and heterosexuals, who frequently use oral aphrodisiacs and psychoactive drugs (nitrite inhalants, cocaine); and 7 per cent haemophiliacs, recipients of transfusions and babies of drug-addicted mothers ${ }^{3++}$ ?

And why does a sexually transmitted disease remain almost exclusively (more than 90 per cent) male - now for nine years, in a free country like the United States ${ }^{+}$? And why does HIV-neutralizing ciplines. In addition to lectures, examinations and scientific research, a clinical professor must devote time to patients, and a surgeon also has to perform operations. They both have heavy teaching loads in postgraduate medical schools. Associate professors in all Italian universities receive the same salary.

I have no comment on the decision not to appoint younger colleagues. But in every free assembly, from parliament to faculty meetings, everybody can express an opinion and, eventually, the majority approves or rejects. But if a proposal is democratically rejected, it is not fair to complain.

Perhaps I am not a black sheep in the eyes of Amati et al. Although I have been assistant and then associate professor at Rome University since 1962, I have not even a stool in the pediatric department where I have worked since 1964 . What has frustrated me has been the refusal of either the university rector or the faculty dean to help.

Istituto di Clinica Pediatrica,

Arnaldo Cantani University of Rome "La Sapienza", O0161 Rome, Italy

antibody (the AIDS test) indicate a virus that has yet to become pathogenic? And why is the cytotoxic DNA chain terminator AZT prescribed to sick and healthy persons who carry a dormant provirus in only 1 of 500 lymphocytes ${ }^{2.3}-$ a "perilous" attack on "molecular minutiae"?

As a virologist, I understand Weiss and Jaffe's fascination with infectious agents. But it is romantic, not scientific, to abandon proven rules such as Koch's postulates without providing new ones to accommodate HIV as the cause of AIDS. Thousands of lives have been lost in the past because medical scientists, inspired by successes of the germ theory, have misdiagnosed as infectious diseases vitamin deficiencies, such as pellagra in the United States ${ }^{5}$ or scurvy in the United Kingdom ${ }^{5}$, and recently a drug-induced neuropathy in Japan ${ }^{6}$. Because the virus-AIDS hypothesis has yet to save a single life, ridiculing a testable alternative ${ }^{3}$ might be "perilous".

\section{Department of Molecular and}

Peter H. Duesberg

Cell Biology,

University of California,

Berkeley, California 94720, USA

1. Weiss, R.A. \& Jaffe, H.W. Nature 345, 659-660 (1990).

2. Duesberg, P.H. Proc. natn. Acad. Sci. 86, 775-764 (1989).

3. Duesberg, P.H. Res. Immun, 141, 5-11 (1990)

4. US Dept of Health and Human Services HIV/AIDS Surveillance (Centers for Disease Control, January 1990).

5. Bailey, H. The Vitamin Pioneers (Rodale, Emmaus, Bailey,

1985). Kono, R. \& Shigematsu, J. Jap. J. Med. Sci. Biol. Suppl. 28, 1-21 (1975).

\section{Role of religion}

SIR-I would be surprised if there should be any field of enquiry not open to the pages of Nature. Religion has important sociological functions and is therefore susceptible to scientific analysis. While Christopher J. Lote may consider religion to be destructive (Nature 346, 10; 1990), there is evidence that religion has a role in maintaining social structures and establishing patterns of behaviour with concepts of fairness, justice and altruism. To dismiss any discussion of religion would seem premature when the data have rarely been objectively assessed.

In a straw poll conducted in this hospital of medical staff, 13 out of 20 had a religious belief, a prevalence significantly greater than found by Lote. Small studies are probably unhelpful in establishing whether there is any relationship between science and atheism.

Science and faith in God need not be contradictory, as Lote proposes. Religions of the Judaeo-Christian tradition would appear to suggest that observation can substantiate their claims (Psalm 19:1-4; Romans 1:20). Is the existence of God a testable hypothesis? Christians would claim that performing the appropriate experiment (Romans 10:9-13) will result in revolutionary and therefore observable changes (1 Corinthians 5:17).

GRAHAM BothamLEY

Department of Thoracic Medicine,

London Chest Hospital,

Bonner Road,

London E2 9JX, UK

SIR-I hope you will run an opinion poll such as that suggested by Christopher Lote. In the meantime, can your regular reader and occasional correspondent God, through one of His/Her agents, put my mind at rest on the following matter? In the United Kingdom, we have what is called the national anthem, comprising words and a tune. When the tune is played, the act of standing implies acceptance of the words (at least, of the first verse), beginning "God save our gracious Queen. . .". Clearly, God is not just any kind of god. He/She is not one who, having created the Universe, leaves it to run itself ever after; He/She may be sensitive to our supplications and is able to intervene on behalf of a named individual.

So does the national anthem imply a national theology, perhaps that of the established church? If so, some may not want this; the proposed poll could show how many. To avoid controversy, should not the song be renamed the religio-royal anthem?

\section{Yarnells Hill,}

Oxford

OX2 9BE, UK 